\title{
Motorcyclists' Mortality Pattern in Colombia from 2000 to 2013: A Longitudinal Study
}

\section{Rodríguez-Hernández Jorge Martín ${ }^{1}$, Camelo-Tovar Fredy¹, Albavera-Hernández Cidronio 2*, Campuzano-Rincón Julio Cesar ${ }^{3}$}

${ }^{1}$ Institute of Public Health, Pontificia Universidad Javeriana, Colombia

${ }^{2}$ Mexican Social Security Institute, ULA University Latinoamerican, Mexico

${ }^{3}$ National Institute of Public Health, Cuernavaca, Morelos, Mexico

${ }^{*}$ Corresponding author: Albavera-Hernández Cidronio, Mexican Social Security Institute, ULA University Latinoamerican, Mexico, Tel: 01 7771611896; E-mail: cidalbavera@gmail.com

Received date: July 24, 2017; Accepted date: August 04, 2017; Published date: August 07, 2017

Citation: Rodríguez-Hernández JM, Camelo-Tovar F, Albavera-Hernández C, Campuzano-Rincón JC. Motorcyclists' Mortality Pattern in Colombia from 2000 to 2013: A Longitudinal Study. Arch Med. 2017, 9:4

Copyright: (c) 2017 Rodríguez-Hernández JM, et al. This is an open-access article distributed under the terms of the Creative Commons Attribution License, which permits unrestricted use, distribution, and reproduction in any medium, provided the original author and source are credited.

\section{Abstract}

Background: Road traffic injuries and fatalities have increased in Colombia despite that 2011-2020 had been declared as the Decade of Action for Road Safety in the world. Then, this paper aims to describe the trends of motorcycle mortality patterns in Colombia from 2000-2013.

Methods: A longitudinal study is carried out using mortality records from the Colombian National Department of Statistics, and following the International Classification of Diseases -ICD-10 V200 to V299.

Results: From 2000 to 2013 the study founded a near 100\% increase in the number of motorcycle fatalities in Colombia; the occurrence rate increased from 3.6 to 5.7 per 100,000 populations. $65.4 \%$ of the fatalities involve individuals from 15 to 34 years of age.

Conclusions: Motorcycle fatalities have become a serious public health issue in Colombia. For the 14-year of the study period, slightly more than 28,800 motorcyclist's deaths have been attributed to different factors and social determinants.

Keywords: Motorcycles; Colombia; Mortality rates; Decade of action for road safety

\section{Introduction}

The 2004 World Report from the World Health Organization states that the Road Traffic Injury (RTI) is becoming an ever growing public health issue [1]. According to the report, related road traffic disasters represent the number one cause of death due to injury, the eleventh cause in the general mortality population, and it is ranked the ninth cause in the global burden of disease [2]. The report also shows that around 1.3 million of population worldwide loses their lives every year due to road traffic injuries, and the Western Hemisphere is far from being the exception, as nearly 150,000 fatalities per year are confirmed [3]. In 2010, Latin America had an average rate of 16.3 per 100,000 populations, practically twice the average shown in countries where population earned a high income, which revealed rates of around 10 per 100,000 populations. A problem that is widely outpacing the average registered in countries such as Denmark (3.5), Australia (5.4), Germany (4.3), France (5.1), Ireland (4.1), Japan (4.7), Canada (6.0), United States (10.6) [4]. Projected estimations show that by 2020 the average rate in the Latin America region could be reaching $24 / 100,000$ population. If this prediction comes to pass, it would represent a true challenge to the economic and social development of the countries comprising this region $[3,5]$.

The expenditure due to crashes and health care services for those traffic injuries are estimated to be around $1 \%$ of the gross domestic product (GDP) in low-income, $1.5 \%$ in middle-income countries, and $2 \%$ in high income countries. Healthcare costs due to RTI are estimated to represent between $1.6 \%$ to $4.2 \%$ of Colombia's GDP in 2010 [3].

Although in recent years the global mortality rate due to RTI has decreased, in most Latin American and Caribbean countries this reduction has not been evenly distributed among road users. The study conducted by Rodrigues et al. [6] shows that the motorcyclists' fatal injury pattern increased on the entire continent from 1998 to 2010, especially for the Andean subregion countries. The study also reported that the increasing of the mortality-rate might be a result of recent economic changes, a rapid increase in motorization rates, and a lack of public transportation policies oriented to the need of discouraging the use of private vehicles $[6,7]$. In addition, factors such as the growth in motorcycle sales, higher cost of fuel for regular 4wheels vehicles, and the generalized idea-along with the misleading conception that motorcycles are more environmental friendly (among others) have also been related to this increasing phenomenon [8-19]. 
Moreover, it has also been corroborated by several authors that in low-income countries the high incidence of mortality rate is a result of several circumstances, such as negligible use of personal protective equipment, slight low enforcement, frequent breach of traffic laws, driving at high speeds, culture of diving in zigzag patterns, use of cell phones while driving, and low perception of risk on unsafe driving conditions with little traffic signals [20-29].

Thus, regarding to the Colombian' situation, this country occupies the fourth position in South America's territorial extension, and the third in population growth in Latin America, after Brazil and Mexico; and according to the National Administrative Department of Statistics [30], the country had a population of 47'120,770 inhabitants in 2013, living in 33 decentralized territorial provinces [31]. Colombia also has the fourth largest regional GDP, and among the whole world the country is ranked in the 30th position. Particular condition that partially allows to explain the increase in purchasing fourwheels, and primarily, two-wheel vehicle; a trend that has been steadily happening for the last 10 years [32,33].

Among the 2000 to the 2013 year, Colombia increased considerably the number of registered motorcycle vehicles, coming from $32.8 \%$ to almost $50 \%$, and virtually doubling the number of car in $29.0 \%$, as a mean of transportation [34,35]. Similarly, in recent years, the participation of this type of vehicle in road accidents has shown a significantly growth, especially for deadly events [36]; that is, representing $24 \%$ of all road deaths in 2001 to around 45\% in 2010 [37-39]. Therefore, this article aims to analyze the pattern of motorcyclists' mortality for the Colombian population between the 2000 and 2013 year, following a list of variables from the official Colombian mortality registered records.

\section{Materials and Methods}

\section{Study Design}

A longitudinal-descriptive study of motorcyclists' mortality in Colombia from 2000 to 2013, using records from the Colombian National Administration Department of Statistics (DANE is the Colombian acronym), was implemented. The events classified as death due to motorcycle accidents were extracted from the mortality database using codes V20 to V29 according to the tenth edition of the International Classification of Diseases (ICD 10).

\section{Data Processing}

The variables analyzed for this study are: year (2000 to 2013), Month (January to December), Age (discrete variable from 0 to 99 years of age), Sex (Male, Female), causes according to ICD 10 codes (as mentioned above), and provincial and municipal locations - where the fatality took place. Similar to the large population groups, which have been used for the study of injuries and deaths from external causes $[1,40]$, age-groups are gathered following specific categories (under 15, from 15 to 34 , from 35 to 59, and 60 and over). Specific rates are also calculated for each year, based on the DANE's population projections and reported per 100,000 populations.

\section{Data Analysis}

As stated before, a longitudinal descriptive analysis was carried out from the 2000 to 2013 year. The specific mortality rates are calculated according to provincial, municipal, sex, and age-group data, from the first to the last year of the study period. To make better comparisons among different provinces and municipalities, adjusted mortality rates, using the direct standardization method with $95 \%$ confidence intervals, were obtained. Then, the same proportional distribution used by the WHO-2000 standard population was applied to each specific rate by age-groups, allowing, therefore, to make properly adjustments in population structure differences toward each compared groups [41].

Using that estimation, the mortality risk for each provincial territory is ranked as one out of five categories: very low (below the $10^{\text {th }}$ percentile); low (from the $10^{\text {th }}$ to the $25^{\text {th }}$ percentile); average (from the $26^{\text {th }}$ to the $75^{\text {th }}$ percentile); high (from the $76^{\text {th }}$ to the $90^{\text {th }}$ percentile); and very high (over the $90^{\text {th }}$ percentile). Additionally, the software used in the analyses was State 13.2 and Microsoft Excel 2013. The results of the study were also geo-referenced on maps, using the software ArcGIS version 10.4 .

Finally, Poisson Regression was the model applied for this multivariate analysis, aimed at estimating the incidence of relative risk (IRR in the equations, using 95\% confidence intervals $(\mathrm{Cl})$ and a $\mathrm{p}$ value $<0.05)$. The general population is considered the exposure variable, with the dependent variable represented by the number of fatalities and the independent variables classified as: Sex ( $0=$ Female, $1=$ Male); Period (2000-2004=0, 2005-2008=1, 2009-2013=2); Age-Group (under $15=0,15$ to $34=1,35$ to $59=2,60$ and over=3); Provincial Territory (Antioquia=1, Bogotá=2, Valle del Cauca=3, Meta=4, Cesar $=5$, Guajira $=6$, Rest of the Country $=0$ ), and having in mind as well that other variables were used just for model adjustment purposes.

\section{Ethical Aspects}

The present study did not require approval from any Ethics Committee, since according to the Law Act, Resolution 008430, from the Colombian Ministry of Health in 1993, this kind of research is considered to have no risk. The study is, exclusively, using secondary data, among which there is no personal information regarding to any deceased individual, and therefore, private information is not comprised.

\section{Results}

From 2000 to 2013 fatal road traffic injuries took the lives of 24,881 motorcyclists, $86.6 \%$ of whom were men. But, during that period, while the standard rate of mortality due to RTI in Colombia dropped from 19.8 to 14.3 per 100,000 populations, motorcyclist fatalities increased steadily until becoming the number one cause of traffic fatalities, representing eventually 
nearly $40 \%$ of total traffic fatalities in 2013 . In other words, the retrospective analysis clearly shows how much in a country like Colombia the annual motorcyclist fatalities increased constantly during the period of study. As can be seen on the annexed graph, from 2000 to 2005 there is a slight decrease of fatalities due to this cause, which is interrupted by a sudden increase in 2006, remaining steady until the end of the study period (Figure 1 ). The number of deceased persisted as to 1,800 fatalities per month with some peaks in June (8.7\%) and in December (9.5\%), probably associated with traffic increase during those vacation periods.

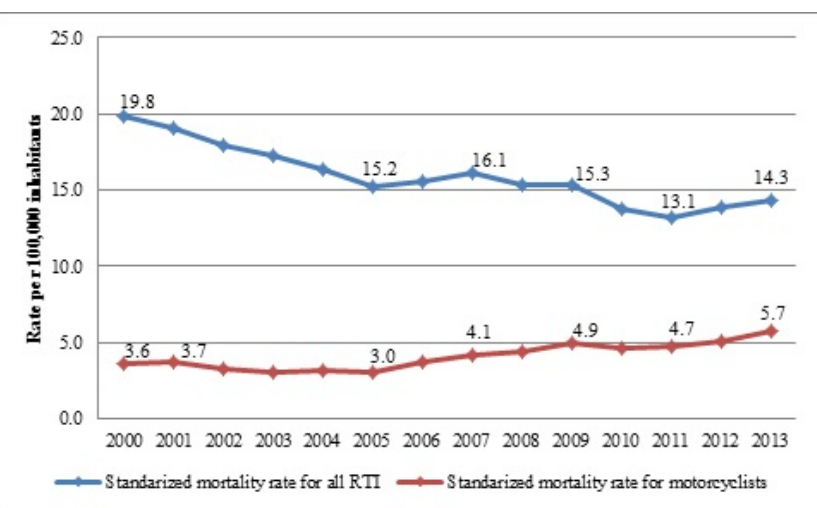

Figure 1: Gross mortality rates for all Road Traffic Injuries and among Motorcyclists. Colombia, 2000-2013, Adapted from Colombian National Statistics Department (2013).
The age-group from 15 to 34 years contributed to the $65.4 \%$ of fatalities, particularly within the youth group aged 20 to 24 years whom comprised $20.7 \%$ of the cases. For the following age-groups there is evidence of a rapid decrease in the number of fatalities all the way down until the elderly group aged 60 to 64 , who represented $1.4 \%$ of the fatalities. Yet, it is important to point out that similarities of $1,8 \%$ between the elderly group and motorcyclist's fatalities under the 15-year-olds group were observed (Table 1). A little over $60 \%$ of all motorcyclist fatalities during the study period are located and concentrated in eight provincial territories: Antioquia (17.5\%), Valle (15.2\%), Bogotá (6.7\%), Huila (5.1\%), Santander (5.1\%), Meta (4.4\%), Tolima (4.3\%), and Cundinamarca (4.2\%). However, after adjusting the mortality rate per 100,000 populations, a different picture is shown; which is demonstrated by the fact that in 2013 the provincial territories had the following percentage: Casanare (22.1), Arauca (17.5), Huila (14.9), Meta (13.6), Cesar (12.9), Putumayo (9.7), Tolima (8.5), and Santander (6.5). Also, it is important to stand out that although Antioquia and Valle together gathered $33.7 \%$ of the fatalities, they have an average similar to the national rate of 5.7 per 100,000 populations.

The increase in this phenomenon has been so dramatic that none of the 33 provincial territories showed a downward trend at all. During the 14-year study period, in some more than others, the Provincial Territories shown a pronounce upward increase. For instance, the provincial territory of Cesar increased its motorcyclist mortality rate by $426 \%$, Putumayo by $314 \%$, Casanare and Arauca by $253 \%$ and $230 \%$, respectively.

Table 1: Motorcyclists mortality by age groups. Colombia, 2000 to 2013 (Source: Colombian National Statistics Department 2013).

\begin{tabular}{|c|c|c|c|c|c|c|}
\hline Age groups & Female & $\%$ & Male & $\%$ & Total & $\%$ \\
\hline 0 to 4 years & 48 & 1,44 & 53 & 0,25 & 101 & 0,41 \\
\hline 5 to 9 years & 39 & 1,17 & 44 & 0,20 & 83 & 0,33 \\
\hline 10 to 14 years & 105 & 3,15 & 175 & 0,81 & 280 & 1,13 \\
\hline 15 to 19 years & 516 & 15,47 & 1939 & 9,00 & 2455 & 9,87 \\
\hline 20 to 24 years & 674 & 20,21 & 4488 & 20,83 & 5162 & 20,75 \\
\hline 25 to 29 years & 520 & 15,59 & 4367 & 20,27 & 4887 & 19,64 \\
\hline 30 to 34 years & 408 & 12,23 & 3195 & 14,83 & 3603 & 14,48 \\
\hline 35 to 39 years & 303 & 9,09 & 2299 & 10,67 & 2602 & 10,46 \\
\hline 40 to 44 years & 248 & 7,44 & 1665 & 7,73 & 1913 & 7,69 \\
\hline 45 to 49 years & 167 & 5,01 & 1204 & 5,59 & 1371 & 5,51 \\
\hline 50 to 54 years & 100 & 3,00 & 785 & 3,64 & 885 & 3,56 \\
\hline 55 to 59 years & 66 & 1,98 & 532 & 2,47 & 598 & 2,40 \\
\hline 60 to 64 years & 52 & 1,56 & 302 & 1,40 & 354 & 1,42 \\
\hline 65 to 69 years & 30 & 0,90 & 204 & 0,95 & 234 & 0,94 \\
\hline 70 to 74 years & 24 & 0,72 & 102 & 0,47 & 126 & 0,51 \\
\hline 75 to 79 years & 11 & 0,33 & 67 & 0,31 & 78 & 0,31 \\
\hline
\end{tabular}




\begin{tabular}{|l|l|l|l|l|l|l|}
\hline 80 and more & 14 & 0,42 & 65 & 0,30 & 79 & 0,32 \\
\hline No data & 10 & 0,30 & 60 & 0,28 & 70 & 0,28 \\
\hline Total & 3335 & $100 \%$ & 21546 & $100 \%$ & 24881 & $100 \%$ \\
\hline
\end{tabular}

As well, other provincial territories such as Norte de Santander, Boyacá, Risaralda, Cauca, Cundinamarca, Atlántico, Córdoba, Sucre, Nariño and Bolívar doubled the rate at which they started out from the study period $(p<0.05)$ (Figure 2$)$. Thus, after making the appropriate adjustment for the mortality rates by age and sex using the Poisson Model, the provincial territory that shown the greatest risk of deaths (for men) was San Andrés, with an IRR of 6.00 (Cl 95\%: $5.06 \pm 7.13$ ), followed by Casanare 3.07 (Cl 95\%: $3.38 \pm 2.78$ ), Arauca 2.88 (Cl 95\%: $3.29 \pm 2.52$ ) and Meta 2.1 (95\% Cl: $2.24 \pm 1.96)$ (Figure 3).

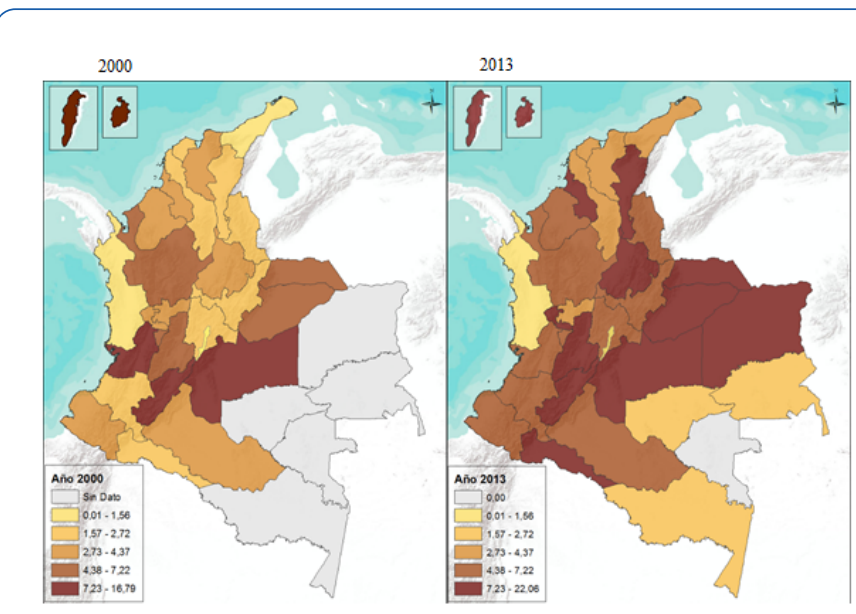

Figure 2: Evolution of motorcyclists' mortality by department in Colombia 2000-2013, Adapted from Colombian National Statistics Department (2013) (*Not statistically significant).

Poisson Regression analysis showed that for this study period, the men group had a significantly higher risk of dying as motorcyclist, with a IRR $4.51(95 \% \mathrm{Cl} 4.3 \pm 4.7)$, compared to women, after carrying out adjustments for other independent variables included in the final model, such as age-groups, periods of time and provincial territories.

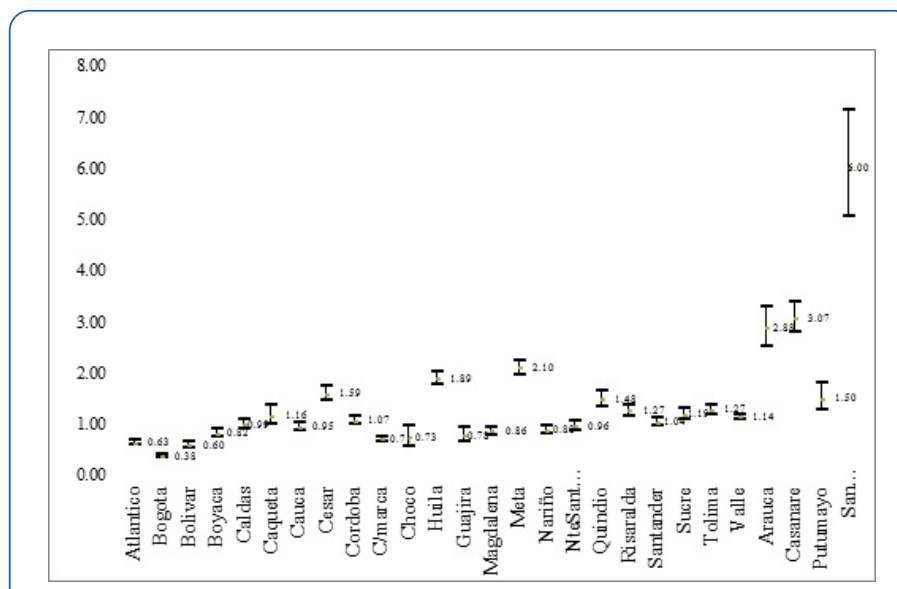

Figure 3: Relative Risk Motorcyclists' departmental mortality (adjusted for age and sex), Colombia, 2000-2013 (Source: Own calculations using Colombian National Statistics Department data records 2013).

Likewise, compared with other age-groups, the analysis shows an increased risk of death among those aged 15-34, with a IRR of $8.74(95 \% \mathrm{Cl}: 7.97 \pm 9.60)$ and those aged $35-59$ with a IRR 5.78 (95\% Cl 5.26-6.35). On the other hand, the analysis also suggested increased risk associated with time; since during the study period (2000-2013) there was an increase of $34 \%(95 \% \mathrm{Cl}$ $1.30 \pm 1.38$ ) throughout the country, when matched up to the category used as reference (2000-2004). Finally, when analyzed by provincial territories, during the study period of fourteen years, the risk of dying was higher in Meta, Cesar, Valle and Antioquia $(p<0.001)$ (Table 2).

Table 2: Mortality risk among motorcyclists in Colombia 2000-2013 (Source: Own calculations using Colombian National Statistics Department data records 2013).

\begin{tabular}{|c|c|c|c|c|}
\hline Variable & RRI & \multicolumn{2}{|c|}{ Cl $95 \%$} & $p$ value \\
\hline \multicolumn{5}{|l|}{ Sex } \\
\hline Women (Ref) & 1 & & & \\
\hline Men & 4.51 & 4.35 & 4.68 & $<0001$ \\
\hline \multicolumn{5}{|l|}{ Age groups } \\
\hline < 15years(Ref) & 1 & & & \\
\hline 15 to 34 years & 8.74 & 7.97 & 9.6 & $<0001$ \\
\hline 35 to 59 years & 5.78 & 5.26 & 6.35 & $<0001$ \\
\hline$\geq 60$ years & 4.17 & 3.72 & 4.67 & $<0001$ \\
\hline
\end{tabular}




\begin{tabular}{|l|l|l|l|l|}
\hline \multicolumn{2}{|l|}{ Period } & 1 & & \\
\hline 2000 to 2004 (Ref) & 1.09 & 1.06 & 1.13 & $<0001$ \\
\hline 2005 to 2008 & 1.34 & 1.3 & 1.38 & $<0001$ \\
\hline 2009 to 2013 & \multicolumn{5}{|l|}{} \\
\hline Departments & 1 & & 1.14 & $<0001$ \\
\hline Other departments (Ref) & 1.11 & 1.07 & 0.4 & $<0001$ \\
\hline Antioquia & 0.38 & 0.36 & 1.62 & $<0001$ \\
\hline Bogotá & 1.5 & 1.4 & 0.77 & $<0001$ \\
\hline Cesar & 0.65 & 0.55 & 2.25 & $<.0001$ \\
\hline Guajira & 2.11 & 1.99 & 1.32 & $<.0001$ \\
\hline Meta & 1.28 & 1.23 & \\
\hline Valle & & & \\
\hline
\end{tabular}

\section{Discussion}

Between 2000-2013 there was a 94\% increase in the number of deaths associated with motorcyclists in Colombia, having also the incidence-rate increase from 3.6 to 5.7 per 100.000 populations. Slightly more than $60 \%$ of the total mortality was concentrated in eight provincial territories (Antioquia, Valle, Bogota, Huila, Santander, Meta, Tolima, and Cundinamarca). However, compared with the national average $(p<0.05)$, the adjusted mortality rates in states such as Arauca, Casanare, Huila have shown a significantly increase in the study period (Figure 2). The motorcycle mortality seems to be concentrated in states with greater economic income, which is consistent with better regional road infrastructure and higher number of registered vehicle $[29,33,42-48]$.

The high mortality growth in states such as Casanare, Meta and Cesar, in which adjusted mortality rates increased significantly during the study period $(p<0,05)$, might be consistent with the existence of a "geographical gradient" in traffic accidents. That is, while interior and more developed regions have higher number of deaths, so do peripheral regions; but in practice, the later ones have much less regulatory law compliance and enforcement, making it more difficult to know the real picture $[23,49]$ with a bigger risk of death $[24,33,36]$.

Previous studies have identified multiple factors associated with the upward trend of motorcycle's mortality in Colombia. Researchers from the extinct National Prevention Road Fund, in 2012, estimated improper use of the helmet in $65.5 \%$ of motorcyclists, especially in cities greater or equal to 900,000 populations [29].

These data are consistent with the report from Rodríguez et al. [39], which in addition to showing low helmet's wearing in two intermediate cities of the Colombia; they found that in general motorcyclists do not wear helmets because of hygienic and cultural reasons, harsh climatic conditions, and lack of organizational police enforcement.

Moreover, another determining factor that has been identified is the fact that many motorcyclists are not aware of their greater vulnerability to traffic accidents [26,50]. Different behavioral patterns in regional studies from Colombia may somewhat explain why motorcyclists suffer more traffic accidents. Among them, the following factors has been observed: most of motorcyclist do not respect red lights; very often they ride on sidewalks and on pedestrian walkways; they make zigzag driving movements in and out of cars and lanes; they do not wear motorcycle helmet, or if they do, they do not wear it correctly or do not wear the type of helmet that provides the best safety conditions [51-59]. Additionally, few of them use reflective vests even during the hours that it is mandatory; the backseat riders do not use personal protection gear [6]; very often motorcyclists ride at excessive speed, and they do not stay in before the lane when they stop at red lights $[27,32,39,53,60-63]$.

However, it is known that such risky behaviors are not exclusive of Colombian motorcyclists; various authors have described similar patterns in other parts of the world. Patterns of zigzagging through traffic, talking on a mobile phone while driving, not wearing a motorcycle helmet or using it incorrectly, not using reflective gear, violating traffic regulations, speeding, and driving under the influence of alcohol have been positively associated with the increasing risk of fatalities that motorcyclists around the world are frequently expose to, when involved in traffic accidents $[1,7,25,49]$.

Moreover, the results obtained in this study allowed to corroborate that in Colombia, similarly to other countries, deaths related to traffic accidents, especially in motorcyclists, are concentrated on men [4]. In this regard, it has been reported that men are more likely to drive at high speeds or to do so under the influence of alcohol (that is, with patterns of speeding, drinking and driving), having much more confidence while driving in risky situations [64-73].

But, unfortunately, this study fails to provide specific interpretations of how gender roles determine activities such as drinking and driving, exposure to risky behaviors and the likelihood of dying from road collisions. The high incidence of mortality rate among population 15 and 34 years of age could be 
related to limited skills and abilities to drive [74], lack of knowledge of road safety rules [27], lack of technical expertise to make decisions in risky situations and "overconfidence" [75-78].

This study has as framework a generalized linear model where the dependent variable is a numeric variable; which it is supported by current research, indicating the utility of such approaches for studies in public health with this kind of features [79-84]. There are some critics that mention possible risks and limitations with this approach. Even so, it is considered that these aspects cannot be related to the present study, because the authors followed the assumptions of equal dispersion and integrity of the data, attributes that have been left intact. However, another alternative could have been the application of time series analysis, but there are not complete, and in detail information to do so.

Another important constraint in this study is not having further details of the events, such as type of motorcycle, speeding patterns, drinking and driving behavior, wearing of helmets, severity of injuries etc. [85-91]. On the other hand, the records were, also, not correlated, with basic information such as policies to ease purchase of vehicles, price of gas, motorcyclist's perceptions and preferences for using a type of vehicle, among others [92-95].

Finally, this research has the typical limitations of population studies that are based on secondary source, as the current example with death certificate records; which usually have considerable errors, such as in recording, coding and classification -among others [54,96,97]. However, the authors believe that in this case these potential data flaws are highly controlled by the strict validation and reclassification systems used by the Colombian National Administration Department of Statistics (DANE). As well, another important limitation is that this kind of source with secondary mortality records does not identify causes, risk factors and/or possible determining factors regarding the occurrence of motorcyclist fatalities. For instance, there are not identifications of factors such as social and cultural variables (level of income and driving practices, etc.); individual variables (drinking and driving habits, risky behaviors, wearing of a motorcycle helmet, driving skills, type of helmet used, etc.), vehicle variables (make, model, size, etc.), and environmental variables (speed, road lighting, road signs, appropriateness of road infrastructure, etc.). Similarly, analysis using socioeconomic factors or other social determinants could not be made, because the records shown more than $20 \%$ of underreporting data in crucial variables like the deceased's social strata and education level; therefore, this type of important evaluation had to be excluded.

\section{Conclusion}

Despite of all possible limitations, this work is integrated to the body of evidence on this increasing issue, generating hypotheses related to the behavioral Colombian's motorcycle fatalities and high mortality. Subsequently, it is a way to opening up the discussion for the imperative need of designing and implementing a series of interventions aimed at mitigating this catastrophic result in deaths. Combined aspects that obviously are having a high impact on the social and economic development of the country.

After several months of delay, the Colombian Government, led by the Ministry of Transportation, in December 2015, set up the National Agency for Road Safety, which is expected to promote effectively the policies described on the National Plan for Road Safety in Colombia, during 2014-2021 period, addressing them at the national level and monitoring the implementation at the regional and local level $[98,99]$.

Additionally, it is important to point out that the Colombian government must not be repeating the same mistakes, designing and implementing policies at the regional and local levels that have little chance of law-abiding or being implemented; as it is the case, currently, with much sectorial legislation. It is also imperative that the Colombian government improves the process of control and regulation, adjusting in better way the access, sale and availability of motorcycles, in addition to better parameters of distributing driving licenses and driving schools that issues them. Also, vital aspects such as the compliance and enforcement of the road legislation must be strengthened, along with the mandatory mechanical and technical check of all types of vehicles [6]. It is essential to regulate and penalize patterns of risky behaviors for motorcyclists, as well as for all road players, enforcing the compliance of the legislation in coherence, consistent and articulated way [100].

Finally, it should not be allowed that drivers with a history of multiple breaches and traffic infractions keep doing so; therefore, exemplifying mechanisms for punishment and suspension of licenses must be generated, in order to avoid putting at risk the life of themselves as well as the other road users. These recommendations coincide with the ones included on the most recent report of road safety from the WHO in 2015; in which the report mention the fact that "countries that have been more successful in reducing the number of deaths due to traffic, have achieved this goal by making improvements in legislation, applying and executing the enforcement of those rules, and by building and making safer roads and vehicles" [4].

\section{References}

1. WHO (2004) World report on road traffic injury, Geneva.

2. WHO (2013) Global status report on road safety, Geneva.

3. Inter-American Development Bank (2013) The cost of road injuries in Latin America. Washington.

4. WHO (2015) Global status report on road safety, Geneva.

5. Banco Interamericano de Desarrollo (2013) Diagnosis of road safety in latin America and the caribbean: 2005-2009, Washington.

6. Rodrigues E, Villaveces A, Sanhueza A, Escamilla-Cejudo J (2014) Trends in fatal motorcycle injuries in the Americas, 1998-2010. Int J Inj Contr Saf Promot 21: 170-180.

7. Villaveces A, Cummings P, Koepsell T, Rivara F, Lumley T (2003) Association of alcohol-related laws with deaths due to motor vehicle and motorcycle crashes in the United States, 1980-1997. Am J Epidemiol 157: 131-140. 
8. Paulozzi L (2005) The role of sales of new motorcycles in a recent increase in motorcycle mortality rates. J Safety Res 36: 361-364.

9. Guguraj G (2008) Road traffic deaths, injuries and disabilities in India: current scenario. Natl Med J Indi 21: 14-20.

10. Wilson F, Stimpson J, Hilsenrath P (2009) Gasoline prices and their relationship to rising motorcycle fatalities, 1990-2007. Am J Public Health 99: 1753-1758.

11. Wong Z, Chong C, Tai B, Lau G (2009) A review of fatal road traffic accidents in Singapore from 2000 to 2004. Ann Acad Med Singapore 38: 594-599.

12. Nwadiaro H, Ekwe K, Akpayak I, Shitta H (2011) Motorcycle injuries in north-central Nigeria. Niger J Clin Pract 14: 186-189.

13. Paixãol L, Gontijol E, Drumond E, Friche A, Caiaffal W (2015) Traffic accidents in Belo Horizonte: the view from three different sources, 2008 to 2010. Bras epidemiol 18: 108-122.

14. Rahman N, Baharuddin K, Mohamad S (2015) Burden of motorcycle-related injury in Malaysia. Int J Emerg Med 8:17.

15. Bagley C (1992) The urban setting of juvenile pedestrian injuries: $A$ study of behavioural ecology and social disadvantage. Accid Anal Prev 24: 673-678.

16. Situacion automotriz (2014) BBVA Research, Colombia.

17. Bener A, Crundall D (2008) Role of gender and driver behaviour in road traffic crashes. Int J Crashworthiness 13: 331-336.

18. Regional Studies Center of the Bank of the Republic (2011) The economy of Mototaxism, the case Sincelejo, Cartagena, Colombia.

19. Committee of Japanese motorcycle assemblers (2013) Eighth sociodemographic study of motorcycle users in Colombia.

20. Peek-Asa C, Zwerling C (2003) Role of environmental interventions in injury control and prevention. Am J Epidemiol 25: 77-89.

21. Elvik R, Vaa $T$ (2006) The manual of road safety measures Madrid. Inj Prev 12: 63-64.

22. Persaud B, Hauer E, Retting R, Vallurupalli R, Mucsi K (1997) Crash reductions related to traffic signal removal in Philadelphia. Accid Anal Prev 29: 803-810.

23. Xuequn $Y$, Ke L, Ivers R, Du W, Senserrick T (2011) Prevalence rates of helmet use among motorcycle riders in a developed region in China. Accid Anal pp: 214-219.

24. Zwerling C, Peek-Asa C, Whitten PS, Choi S, Sprince NL, et al. (2005) Fatal motor vehicle crashes in rural and urban areas: Decomposing rates into contributing factors. Injury Prevention 11: 24-28.

25. Liping L, Gongli L, Qien C, Zhang A, Lo S (2008) Improper motorcycle helmet use in provincial areas of a developing country. Accid Anal 40: 1937-1942.

26. Tunnicliff D, Watson B, White K (2011) The social context of motocycle riding and the key determinants influencing rider behavior: A Qualitative investigation. Traffic injury prevention 12: 363-376.

27. Perez-Fuster P, Rodrigo M, ML B, Sanmartin J (2013) Modeling offenses among motorcyclists involved in crashes in Spain. Accid Anal Prev 2: 15

28. Lin M, Kraus J (2009) A review of risk factors and patterns of motorcycle injuries. Accid Anal Prev 41: 710-722.

29. Road Safety Fund Corporation (2014) Prevalence and Characterization of the use of helmet, sobrecupo and transport of minors in vehicles of two wheels. Bogotá, Colombia.
30. DANE (2013) National Quality of Life Survey. National Administrative Department of Statistics, Bogotá, Colombia.

31. National Administrative Department of Statistics (2010) Departmental population projections.

32. Rodríguez-Hernández JM (2014) Situation of motorcycle injuries, the case of Colombia Colombia.

33. Kopits E, Cropper M (2005) Traffic fatalities and economic growth. Accident Analysis and Prevention 37: 169-178.

34. Ministry of Transport (2015) Decree 0787 by which establishes the functions of the internal structure of the National Road Safety Agency and other provisions are dictated, Bogota, Colombia.

35. Ministry of Transport (2015) Transportation in 2014 figures, Bogota, Colombia.

36. Paulozzi LJ, Ryan GW, Espitia-Hardeman VE, Xi Y (2007) Economic development's effect on road transport-related mortality among different types of road users: A cross-sectional international study. Accid Anal Prev 39: 606-617.

37. Vargas-Castillo DA (2014) Behavior of deaths and injuries due to transport accidents, Colombia, 2013, pp: 171-2019.

38. Rodríguez-Hernández JM, Peñaloza-Quintero RE, Ariza-Ruíz LK, Florez-Valero CF, Camelo Tovar FA, et al. (2015) Risk factors associated with injuries caused by traffic and proposals for interventions in the Colombian context. Bogotá: ECOE Ediciones.

39. Rodríguez-Hernández J, Camelo F, Ariza L (2015) Factors associated with the use of protective helmets in two cities in Colombia. Science \& Collective Health.

40. Krug ED (2003) World report on violence and health. Geneva.

41. Schoenbach VJ, Rosamond WD (2000) Understanding the Fundamentals of Epidemiology an evolving text. Chapel Hill: University of North Carolina at Chapel Hill.

42. Single National Traffic Register (2015) Department Automotive department by type of vehicle. Report generated by request of the researcher. Bogota Colombia.

43. Bishai D, Quresh A, James P, Ghaffar A (2006) National road casualties and economic development. Health Economics 15: 65-81.

44. National Administrative Department of Statistics (2013) Press release Monetary Poverty and Inequality in 2012 by departments.

45. The Herald (2014) Mototaxismo sells 103,000 tickets a day in Valledupar.

46. Human City Foundation \& National Road Prevention Fund (2013) Characterization of Colombian motorcyclists. Bogotá 2010, Colombia.

47. García-Villegas M (2011) Inefficiency of law and culture of noncompliance with rules in Latin America. In C. Rodríguez-Garavito (Ed.), Law in Latin America: A map for legal thought of the 21st century, Buenos Aires, Argentina: Siglo Veintiuno Publishers, pp: 161-185.

48. Ghaffar A, Hyder A, Govender V, Bishai D (2004) Road crashes: A modern plague on South Asia's poor. J Coll Physicians Surg Pak 14: 739-741.

49. Ledesma R, Peltzer R (2008) Helmet use among motorcyclists: Observational study in the city of Mar del Plata. Saúde Pública 42: 143-145.

50. McKenna FP (1993) It won't happen to me: unrealistic optimism or illusion of control? Br J Psychol 84: 39-50. 
51. Aristizabal D, Gonzalez $\mathrm{G}$ (2012) Factores asociados al trauma fatal en motociclistas en Medellín 2005 - 2008. Biomédica 32: 112-124.

52. Cabezas E, Mora L, Peña G, Sinisterra J (2015) Characterization of motorcycle fatalities in Ibagué 2008 -2012 University of Tolima. Ibagué 2014, Colombia.

53. Osma-Rueda J (2014) Factors associated with the severity of motorcycle trauma in the metropolitan area of Bucaramanga. Industrial University of Santander Bucaramanga 2011.

54. Rodríguez-Hernández J, Campuzano-Rincón J, Híjar M (2011) Comparing pedestrian injury mortality in Mexico City: Have changes occurred over a decade? Salud Publica Mex 53: 1-9.

55. Investigación BBVA (2014) Automotive situation. Colombia, Colombia.

56. Jacobs G, Aeron-Thomas A, Astrop A (2000) Estimating global road fatalities. Crowthorne: Global Road Safety Partnership.

57. Laflamme L, Diderichsen $F(2000)$ Social differences in traffic injury risks in childhood and youth-A literature review and a research agenda. Injury Prevention 6: 293-298.

58. Lozano R, Naghavi M, Foreman K, Lim S, Shibuya K, et al. (2012) Global and regional mortality from 235 causes of death for 20 age groups in 1990 and 2010: A systematic analysis for the Global Burden of Disease Study 2010. Lancet 380: 2095-2128.

59. Molina G, San Martin J, Keskinen E (2013) Driver traning interests of Spanish sample of young drivers and its relationship with their self-assesment skills concerinig risky driving behavior. Accid Anal Prev 52: 118-124

60. Turner C, Maclure R (2004) Quantifying the role of risk taking behavior in causation of serious road crash related injury. Accid Anal Prev 36: 383-389.

61. Moreno-Lozada S (2012) Deaths and injuries due to transportation accidents. In National Institute of Legal Medicine, Forensis. Data for Life. Bogotá: National Institute of Forensic Medicine and Forensic Sciences, pp: 350-402.

62. Pan American Health Organization (2012) Health in the Americas. Regional overview and country profiles. Washington.

63. Pan American Health Organization (2013) Road Safety Facts in the Region of the Americas, 2013. Washington.

64. Åberg L, Rimmö PA (1998) Dimensions of aberrant driver behaviour. Ergonomics 41: 39-56.

65. Krahé B, Fenske I (2002) Predicting aggressive driving behavior: The role of macho personality, age, and power of car. Aggresive Behavior 28: 21-29.

66. Bener A, Crundall D (2008) Role of gender and driver behaviour in road traffic crashes. Int. J. Crashworthiness 13: 331-336.

67. Clarke DD, Ward P, Truman W (2005) Voluntary risk taking and skill deficits in young driver accident in the UK. Accid Anal Prev 37: 523-529.

68. Claret PL, del Castillo JD, Moleonh JJ, Cavanillas AB, Martin MG, et al. (2003) Age and sex differences in the risk of causing vehicle collisions in Spain, 1990 to 1999. Accid Anal Prev 35: 261-272.

69. Peñaloza-Quintero RE, Salamanca-Balen N, Rodríguez-Garcia J, Beltrán-Villegas A, Rodríguez-Hernandez J (2014) Estimation of disease burden for Colombia 2010.

70. Preston B (1992) Statistical analysis of child pedestrian accidents in Manchester and Salford. Accid Anal Prev 4: 323-332.
71. Rose G (1985) Sick individuals and sick populations. Int J Epidemiol 14: 32-38.

72. Mobility Secretariat of Bogotá (2015) Integrated Information System on fines and penalties for traffic violations for Colombia. II Meeting of Road Safety in Bogotá. Bogotá. Colombia.

73. Tello-Pedraza J (2012) Behavior of homicide in Colombia, 2012. Forensis Data for life, National Institute of Forensic Medicine and Forensic Sciences pp: 121-153.

74. Durbin D, Mirman J, Curry A, Wang W (2014) Driving erors of learner teens: frecuency, natuure and their association with practice. Accid Anal Prev 72: 433-439.

75. Sundström A (2011) The validity of self-reported driver competence: relations between measures of perceived drviver competence and actual driver skill. Transportation Research Part F 14: $155-166$

76. Gregersen NP (1996) Young car drivers: Why are they over representated in the traffic accidents: How can driver training improve their situation? Swedish National road and transport research institute, Linköping.

77. Delhomme P (2000) Comparative optimism for road users: Protection against risk? Psychological Practices 1: 99-109.

78. Perrissol S, Smeding A, Laumond F, Le Floch V (2011) Effect of a road safety training program dirvers' comparative optimist. Accid Anal Prev 43: 478-482.

79. Murray D, Varnell S, Blitstein J (2004) Design and analysis of group- Randomized Trials: A review of recent methodological developments. Am J Public Health 94: 423-432.

80. Cumming $P$, Koepsell $T$ (2002) Statistical and design issues in studies of groups. Inj Prev 8: 6-7.

81. Greenland S (2000) Principles of multilevel modelling. Int J Epidemiol 29: 158-167.

82. Kleinbaum D, Kupper L, Muller F, Nizam A (1998) Applied regression analysis and other multivariate methods. 3rd edn. Thompson Editores.

83. California University (2007) Statistical Consulting Group. Models with Count Data.

84. Ullah S, Finch C, Day L (2010) Statistical modelling for falls count data. Accid Anal Prev 42: 384-392.

85. Salinas-Rodríguez A, Manrique-Espinoza B, Sosa-Rubí S (2009) Statistical analysis for counting data: Applications for the use of health services. Salud Publica Mex 51: 397-406.

86. Braddock M, Schwartz R, Lapidus G, Banco L, Jacobs L (1992) Apopulation-based study of motorcycle injury and costs. Ann Emerg Med 21: 273-278.

87. Lapidus G, Braddock M, Schwartz R (1994) Accuracy of fatal motor cycle injury reporting on death certificates. Accid Anal Prev 26 535-542.

88. Evans L, Frick M (1998) Helmet effectiveness in preventing motorcycle driver and passenger fatalities. Accid Anal Prev 20: 447-458.

89. Farmer C (2003) Reliability of police-reported information for determining crash and injury severity. Traffic Inj Prev 4: 38-44.

90. Gabella B, Reiner K, Hoffman R (1995) Relationship of helmet use and head injuries among motorcycle crash victims in El Paso County, Colorado, 1989-1990. Accid Anal Prev 27: 363-369. 
91. Grossman D, Mueller B, Kenaston T, Salzberg P, Cooper W, et al. (1996) The validity of police assessment of driver intoxication in motor vehicle crashes leading to hospitalization. Accid Anal Prev 28: 435-442.

92. Ostrom M, Huelke D, Waller P (1992) Some biases in the alcohol investigative process in traffic fatalities. Accid Anal Prev 24: 539-545.

93. Zhu H, Wilson F (2015) Stimpson JP. The relationship between gasoline price and patterns of motorcycle fatalities and injuries. Inj Prev 21: 153-158.

94. Woratanarat $P$, Ingsathit $A$, Chatchaipan $P$, Suriyawongpaisal $P$ (2013) Safety riding program and motorcycle-related injuries in Thailand. Accid Anal Prev 58: 115-121.

95. Clarke D, Ward P, Bartle C, Truman W (2007) The role of motorcyclist and other driver behaviour in two types of serious accident in the UK. Accid Anal Prev 39: 974-981.
96. Comstock G, Markush R (1986) Further comments on problems in death certification. Am J Epidemiol 124: 180-181.

97. Celis A, Valdez L, Armas J, Gómez Z (1999) Pedestrian injured in motor vehicle traffic accidents: Mortality in Mexico: 1985-1996. Gac Med Mex 35: 353-358.

98. Congress of the Republic of Colombia (2013) Law 1702 by means of which the National Agency of road safety for Colombia attached to the Ministry of Transportation is created, Bogotá, Colombia.

99. Ministry of Transport (2014) National Road Safety Plan 2013-2021, Bogotá, Colombia.

100. Híjar M (2012) Road safety legislation in the Americas. Mexico. Rev Panam Salud Publica 32: 70-76. 